\title{
Associations between the K232A polymorphism in the DGAT1 gene and performance of Holstein-Friesian dairy cattle in Irish and UK herds
}

\section{B.K. Meredith ${ }^{1}$, R. Mrode ${ }^{2}$, M Winters ${ }^{3}$, J.F. Kearney ${ }^{4}$, E. Wall ${ }^{5}$, D.P. Berry ${ }^{1}$}

${ }^{1}$ Moorepark Dairy Production Research Centre, Teagasc, Fermoy, Co. Cork, Ireland, ${ }^{2}$ Scottish Agricultural College, Sir Stephen Watson Building, Penicuik, EH26, 0PH, United Kingdom, ${ }^{3}$ DairyCo, Agriculture \& Horticulture Development Board, Stoneleigh Park, Kenilworth, Warwickshire, CV8 2TL, United Kingdom, ${ }_{4}^{4}$ Irish Cattle Breeding Federation, High Field House, Bandon, Co. Cork, Ireland, ${ }^{5}$ Sustainable Livestock Systems Group, Scottish Agricultural College, Penicuik, EH26, 0PH, United Kingdom

Email: briankeithmeredith@hotmail.com

Introduction Marker assisted selection is a method to augment traditional methods of animal breeding with genomic information. Changes in the DNA sequence (i.e., polymorphism) of an animal have previously been shown to affect animal performance. One such example is the dinucleotide polymorphism K232A in the DGAT1 gene on BTA14. However, the effect of a polymorphism may differ by production system. The objective of this study was to quantify the association between the K232A polymorphism in DGAT1 in Irish and UK Holstein-Friesian cattle.

Material and methods Genotypes of the K232A polymorphism of 346 Holstein-Friesian sires with a reliability of a least $60 \%$ in both Ireland and the UK for milk production were available for inclusion in the analysis. For the purposes of this study the two alleles at the K232A polymorphism were called the K (lysine) and A (alanine) based on the amino acids encoded by the respective polymorphisms. Daughter yield deviations for milk yield, fat yield, protein yield, milk fat concentration, and milk protein concentration were obtained from the domestic genetic evaluations of the UK and Ireland. The association between the K232A polymorphism and performance was undertaken using weighted mixed models in ASREML (Gilmour et al., 2009) with a polygenic effect. Fixed effects included in the model were country, the number of copies of the $\mathrm{K}$ allele (continuous variable) as well as an interaction between the number of copies of the $\mathrm{K}$ allele and country (i.e., Ireland or the UK). The dependent variable was the DYD of the trait of interest weighted by its respective reliability. Significance was based on the F-statistic.

Results The standard deviation of the DYD for milk yield, fat yield and protein yield in Ireland was $246.1 \mathrm{~kg}, 7.7 \mathrm{~kg}$ and $6.6 \mathrm{~kg}$, respectively; the respective values in the UK were $211.6 \mathrm{~kg}, 6.2 \mathrm{~kg}$, and $5.9 \mathrm{~kg}$. The correlation between DYDs of the 346 sires in Ireland and the UK were 0.92, 0.85, and 0.90, for milk, fat yield and protein yield, respectively. The frequency of the AA, AK and KK genotypes in the 346 sires was $0.50,0.41$ and 0.09 , respectively. Irrespective of country, an A (alanine) to $\mathrm{K}$ (lysine) allelic substitution was associated with a decrease in milk yield and protein yield but an increase in milk fat yield, milk fat concentration and protein concentration (Table 1). The association between the K232A polymorphism and both fat yield and concentration $(\mathrm{P}<0.001)$ as well as milk yield $(\mathrm{P}=0.05)$ differed by country, but no interaction was observed for either protein yield or protein concentration. However, in all instances only the size of the relationship with milk yield, fat yield and fat concentration differed between countries, not the direction of the relationship suggesting a scaling effect as opposed to a re-ranking effect. The size of the association between the K232A polymorphism and production was similar to previous reports in Ireland using 742 sires (Berry et al., 2009) and the direction of the association with milk yield was similar to the direction of the association in a UK study that investigated the association between the K232A polymorphism and daily milk yield in 571 Holstein-Friesian cows (Banos et al., 2008). The proportion of genetic variation explained by the K232A polymorphism for milk, fat and protein yield was $4.1,14.0$ and $0.01 \%$ in Ireland and 4.2, 7.2 and $0.6 \%$ in the UK respectively. Again these results are in agreement with the results obtained by Berry et al (2009) from 742 Holstein-Friesian sires genetically evaluated in Ireland.

Table 1 Allele substitution effect (A being substituted by K) of the K232A polymorphism on milk production in Ireland and the UK as well as the significance of the interaction between the effect of the polymorphism and country.

\begin{tabular}{|c|c|c|c|c|}
\hline Trait & \multicolumn{2}{|c|}{ Substitution effect (standard error) } & \multicolumn{2}{|c|}{ Significance of interaction } \\
\hline & Ireland & UK & F-value & P-value \\
\hline Milk yield $(\mathrm{kg})$ & $-77.61(15.21)$ & $-66.93(12.14)$ & 16.6 & 0.05 \\
\hline Fat yield $(\mathrm{kg})$ & $4.47(0.47)$ & $2.58(0.38)$ & 76.6 & $\mathrm{P}<0.001$ \\
\hline Protein yield $(\mathrm{kg})$ & $-0.90(0.41)$ & $-0.69(0.34)$ & 3.3 & 0.08 \\
\hline Fat concentration $(\% * 100)$ & $13.10(0.89)$ & $7.32(0.49)$ & 171.3 & $\mathrm{P}<0.001$ \\
\hline Protein concentration $(\% * 100)$ & $2.90(0.51)$ & $2.12(0.28)$ & 22.8 & 0.27 \\
\hline
\end{tabular}

Conclusion The $\mathrm{K}$ allele of the $\mathrm{K} 232 \mathrm{~A}$ polymorphism was associated with reduced milk yield and protein yield but increased fat yield and milk composition. The size of the associations was similar in both countries with the exception of fat yield and fat concentration which differed by country with a larger effect in Ireland which also had a larger variance. The K232A polymorphism can be used in Irish and UK breeding programs to increase the accuracy of selection for production traits.

\section{References}

Banos, G., Woollians, J.A., Woodward, B.W., Forbes, A.B. and Coffey, M.P.2008. Journal of Dairy. Science 91,3190-3200 Berry, D.P., Howard, D., O'Boyle, P., Waters, S., Kearney, J.F. and McCabe, M. 2009. Irish Journal of Agriculture and Food. Resources (Submitted)

Gilmour, A. R., B. R. Cullis, S. J. Welham, and R. Thompson. 2009. ASReml reference manual, $2^{\text {nd }}$ edition. 